УДК 327.39(=81):355.07(470)«19»

DOI 10.37724/RSU.2020.67.2.003

\title{
П. П. Рыхтик
}

\author{
Элементы панславизма \\ в официальных документах военного ведомства \\ Российской империи начала XX века: условия проникновения *
}

\begin{abstract}
Рассматривается проблема влияния идеологической концепции панславизма на систему отношений великих держав и малых акторов в Балканском регионе начала XX века. Дается взгляд на теорию панславизма как явления мировой общественно-политической мысли, зародившегося в XIX веке и представляющего собой многосоставное и неопределенное понятие, наполнявшееся различным смыслом отдельными теоретиками. Особое внимание уделяется чертам русского панславизма как одного из ответвлений данного течения, наиболее актуального в рамках общественно-политического дискурса поздней Российской империи. Указывается на влияние на русский панславистский дискурс следующих основных факторов: актуальных задач балканской политики России, образов «братьев-славян», формировавшихся в русском общественнополитическом сознании в XIX - начале XX века, и связанной с данным образом метафоры «славянской взаимности»; развитие и усиление популярности в России к рубежу XIX-XX веков идей славянофилов. Приводится анализ постепенного проникновения элементов панславистского дискурса из комплекса идей поздних славянофилов, в частности на основе работ и речей В. И. Ламанского, в тексты официального характера (планы, донесения, аналитические записки) Генерального штаба (Главного штаба) Российской империи в начале $\mathrm{XX}$ века, посвященные вопросам русского военного и политического влияния в системе международных отношений на Балканах начала XX века. Делается вывод об особенностях данного идеологического проникновения панславистской концепции в ее взаимодействии с образом «малых» южнославянских народов в сознание подданных Российской империи, с мифом о «братьях-славянах», об актуальной политической обстановке, в которой находилась Россия.
\end{abstract}

Балканский регион; Ламанский В. И.; «славянское братство»; русский панславизм; международные отночения

\section{Введение}

Изобретенное во второй четверти XIX века понятие «панславизм» по мере научных и полемических дискуссий и выработки конкурирующих с данным понятием моделей наполнялось разными смыслами и опиралось лишь на малое число общепринятых дискурсивных констант. В результате «панславизм», как констатируют исследователи, не мог быть определен «до конца» ни в среде его сторонников, в том числе и российских, поскольку их позиции различались, ни в среде его оппонентов в России и вне ее границ. Как правило, под последними понимаются державыпротивницы России на европейском континенте [Ливен, 2007]. Одна из распространенных точек зрения заключается в том, чтобы считать «русский панславизм» идеологической конструкцией позднего имперского периода, предстающей естественным продолжением процесса строительства наций. В то же время ряду исследователей он видится проекцией пангерманизма как идеологической основы немецкого имперского и национального проекта [Волков, 1969]. Когда на рубеже XIX-XX столетий в России элементы панславизма стали концептуальной основой внешнеполитической повестки дня [Ковтуненко, 2015], у критиков не оказалось сколь-нибудь внятного ответа, который бы выходил за рамки тезиса о том, что панславизм представляет угрозу для европейской цивилизации [Engelstein, 2009]. Такое замешательство вполне объяснимо слабой информированностью или идеологическим ослеплением. Но точно так же было не ясно, что означало данное понятие для его апологетов в самой России [Григорьева, 2012].

* Рыхтик П. П. Элементы панславизма в официальных документах военного ведомства Российской империи начала XX века: условия проникновения // Вестник Рязанского государственного университета имени С. А. Есенина. 2020. № 2 (67). C. 25-36. https://doi.org/10.37724/RSU.2020.67.2.003

(C) Рыхтик П. П., 2020 
Наиболее очевидно во всех версиях политического панславизма выделяется лишь идея единого славянского государства, которое возникнет в будущем [Аксенова, 2006]. Сроки претворения в жизнь данного проекта, как и сущность его воплощения, уже были предметом спора. Как предполагал еще в середине XIX века его первый исследователь, это мог быть и «великий союз равноправных славянских народностей»; и идея польских панславистов о том, что во главе такого союза станет Польша, которая наделялась статусом некоего славянского мессии и, как итог, статусом лидера; и известная концепция о том, что рано или поздно «славянские ручьи сольются в русском море» [Пыпин, 1864, с. 23], а средоточием славянского мира станет Москва; существовала и концепция демократического панславизма М. А. Бакунина, соединенная с социализмом [Одесский, 2012].

Из русской перспективы вытекало, во-первых, сознание принадлежности к нации-лидеру славянского мира и, во-вторых, привычка покровительственно относиться к иным славянским народам, точно так же, как относятся в семье старшие родственники к младшим [Пыпин, 1864, с. 26]. Хотя русские мыслители и осознавали, что каждый из славянских народов начал свое развитие, в историческом смысле, в одно и то же время отделившись от общего корня, в их текстах все чаще и чаще начинают звучать метафоры «младших братьев-славян», особенно в отношении славян южных. Данная особенность русского панславизма сочеталась с ресентиментом, который в данном случае указывал, по выражению О. В. Павленко, на «несправедливость существовавшего миропорядка по отношению к славянам» [Павленко, 1998, с. 49]. Такое сочетание порождало особое предназначение России - не только сестры всех братьев-славян, но и их сестры-заступницы. Как следствие, с расцветом панславистской концепции в конце XIX — начале XX века эти императивы проникают и в официальные меморандумы и распоряжения военного министерства, где, как кажется на первый взгляд, не должно быть места ни метафорам, ни иным литературным излишествам. Как бы то ни было, в панславизме, по наблюдению А. Н. Пыпина, перед различными славянскими народами «открылось поприще для притязаний национального самолюбия и квасного патриотизма» и «каждая заметная славянская национальность рассчитывала составить свою славу в этом будущем и выставить во всей полноте национальные свойства, составлявшие ее гордость» [Пыпин, 1826, с. 29].

\section{Основная часть}

Среди множества факторов, оказывавших влияние на эволюцию русского панславизма, особо выделяются три основных. Во-первых, это балканская политика России, реализуемая в динамике международных отношений. Во-вторых, нарастание к началу XX века (в контексте внешнеполитических задач и пореформенной трансформации) влияния славянофильства и его наследия, обеспечившего идеологическую основу для новых проектов [Фатеев, 2006]. В-третьих, углубление и распространение представлений о «малых» балканских народах, формируемых травелогами, этнографическими очерками, популярной и художественной литературой [Белов, 2009].

Масштабы амбиций русского панславизма полностью коррелируют с масштабами внешнеполитических сфер влияния России и с ее геополитическими амбициями на Балканах [Писарев, 1985]. По замечанию К. В. Никифорова, «славянская идея» была также связана напрямую и с ситуацией в самой России, ее восприятием в общественном сознании [Никифоров, 2014]. На этом фоне влияние панславистских идей в России находилось во взаимозависимости с распространением славянофильских идей [Павленко, 1998]. К концу XIX века уже не принято говорить о славянофильстве как об особом течении. Считается, что к началу 80-х годов XX века на смену славянофилам пришли панслависты либо что славянофильская концепция эволюционировала в русскую версию панславизма [Кудряшов, 2012]. Последнее неудивительно: почти всегда панславизм казался славянофилам некой силой, способной изменить политический облик Европы под эгидой славян [Ламанский В. И. Об историческом изучении греко-славянского мира в Европе, 2010]. Дискурсивные концепты «братства», «славянского единения» и «взаимного тяготения» характерны для славянофильства уже с середины XIX века. Затем они интегрировались в проекты и инструкции высшего уровня принятия политических решений в Российской империи, таких как, например, планы и приказы русского Генерального штаба в начале XX века.

Для подтверждения этого тезиса обратимся к идеям В. И. Ламанского [Лаптева, 1997]. Его работы в силу заметности данной фигуры в среде славянофилов [Болдин, Прокудин, 2019] можно считать в достаточной степени репрезентативными [Саприкина, 2004]. Исходя из духовной, новозаветной трактовки идеи «братства» через «кирилло-мефодиевскую традицию», распространенную на всех славян [Ламанский В. И. Три мира Азийско-Европейского материка, 
2010], Ламанский пришел к представлению о «славянском братстве» как базису для единения всех «малых» и «больших» славянских этнических групп, так как в нем (братстве) есть «великая сила для одиноких и целых народов» [Ламанский В. И. Россия уже тем полезна славянам... 2010, с. 445446]. В дальнейшем он перенес концепт «братство» через метафору «братство по оружию» на опыт взаимоотношений России и южных славян, в частности на сербов и черногорцев [Ламанский В. И. Речь в Славянском обществе, 2010]. Синтез представлений о трансцендентном, божественном братстве в сочетании с единой языковой традицией в системе идей Ламанского приводит его в определенный момент к созданию теоретического концепта естественного «всеславянского» братства и, прежде всего, братства и единения русских, как наиболее многочисленной ветви восточных славян, и южных славян, так как именно от них в свое время восточные славяне заимствовали единую письменную традицию [Вступительное чтение... 2010]. Естественность же идей подобного объединения В. И. Ламанский оправдывал, в частности, историческим опытом Люблинской унии Польши и «Западной Руси» [Ламанский В. И. Западнославянские вопросы занимательны для нас...; Национальная бестактность, 2010]. Все это в конечном итоге приводит к сакрализации как самого концепта «братство», так и «естественного единения» славян в славянофильстве начиная с середины XIX века [Ламанский В. И. Чтения о славянской истории... 2010].

Исследователи прослеживают влияние на генезис славянофильских идей образа южных славян, отраженного в текстах русских путешественников середины XIX века (или более ранних), которые позднее получили широкое распространение [Открытие «братьев-славян», 2018]. Это позволяет говорить о тесной связи и взаимозависимости всех трех элементов в системе: представления о южных славянах - русский панславизм - славянофильство.

Результаты сопоставительного анализа свидетельствуют о том, что подобными идеями уже в начале XX века оперируют офицеры русского Генерального штаба, воспринимавшие их, очевидно, из царившего тогда в общественном сознании панславистского дискурса. С использованием таких аргументов, как «естественное тяготение [к России]», принадлежность «к числу естественных союзников России» «по симпатиям и убеждениям массы своего населения» (применительно к «малым» южнославянским государствам), в планах Генштаба оправдываются дипломатическое и военное вмешательство России в их внутреннюю и внешнюю политику. В них так же явно проступает искренняя вера их составителей в то, что подобные метафоры и концепты всецело разделяются и самими южнославянскими народами [Потапов, 2003, док. 3]. Здесь, в частности, говорится о том, что сами «логика и исторический ход событий... подсказывают... правительствам этих государств, что их будущее тесно связано с Россией и что в силу этого они должны быть такими же преданными и искренними союзниками ее, как и управляемые ими народы» [Там же, с. 30-31].

При этом периодически возникающие проблемы, связанные с негативной реакцией на такое вмешательство при проведении на Балканах русского внешнеполитического курса, объясняются чуждым влиянием. Они увязываются, вопреки прежней логике, не симпатиями по отношению, например, к Германии или Австро-Венгрии, но тем, что в ряды важнейших государственных деятелей [Сербии и Болгарии] проникают лица, находящиеся под сильным влиянием австровенгерской дипломатии» [Потапов, 2003, док. 3, с. 31]. Даже благоприятные прогнозы в отношении попавшей под влияние Тройственного союза Румынии оправдывались в русском Главном штабе мнением, что «симпатии средних и низших классов населения направлены в сторону России, нежели Австрии и [следовательно] между населением и правительственными слоями нередко замечается сильная рознь» [Там же]. Благодаря этому Россия будет способна выступить в роли «старшего и могучего члена в семье будущих свободных и прочных славянских народов» [Там же, с. 43].

При рассмотрении в записках Генерального штаба вопроса о целесообразности сохранения и увеличения русских военных субсидий для Черногории в марте 1908 года присутствуют такие же апелляции. Речь идет о «симпатии черногорского народа к России и ненависти его к другим иностранцам, входящим с ними в соприкосновение», что позволяет России надеяться на использование черногорской силы «в случае осложнений на Балканах» [Потапов, док. 178, с. 336]. Анализируя же позицию черногорского князя Николая относительно выбора прорусской или проавстрийской линии, среди главных причин, не дающих князю склониться к окончательному выбору «австрийской» линии, предполагается неприятие такой политики в среде простого черногорского народа, желающего видеть союз своей страны с «братской» Россией [Там же, c. 333-337]. Таким образом, панславистский дискурс выступал для офицеров русского Генерального штаба некоей моделью, объясняющей наблюдаемые ими политические проявления, 
при этом определенный романтический ареол данной модели, по-видимому, не смущал офицеров штаба. Причиной этому, с одной стороны, можно считать сам факт распространения панславистского дискурса в их среде, что делало его в достаточной степени естественным, а с другой стороны, сказывалось то, что многие русские гвардейские офицеры времен поздней Российской империи характеризуются М. М. Фроловой как «литературно одаренные люди, составлявшие элиту не только русской армии, но и русского общества» [Фролова, 2017, с. 88].

Определенный «фильтр братской концепции» в отношении южных славян проявлялся и в восприятии русскими, пребывавшими на Балканах, в том числе и по линии военного ведомства. Представителем такой группы наблюдателей был, например, военный агент в Черногории с 1903 по 1914 год Н. М. Потапов. Примечательно, что его задачами как военного агента было не только выяснение вопросов военного характера, таких как состояние и реформирование черногорской армии, но и выяснение текущих политических предпочтений и интересов черногорских элит и населения княжества [Потапов, док. 22, с. 71-72]. В частых и кратких по своему содержанию рапортах и донесениях, связанных, например, с ходом Боснийского кризиса 1908-1909 годов и реакцией на него в Черногории, сам Потапов обычно не использовал метафор, характерных для панславистского дискурса [Потапов, док. 179-188, с. 338-345]. Однако, к примеру, в пространном рапорте от октября 1908 года, повествующем о подробностях его бесед с черногорским князем Николаем о проблеме аннексии Боснии и Герцеговины, подобные формулы нашли свое место. Риторическую игру начал сам князь Николай, требуя от «сестры» России защиты и покровительства как само собой разумеющегося: «Разве я не заслужил доверия России?» [Потапов, док. 189, с. 346]. Он выражал недовольство, поскольку империя медлила тогда с подобной помощью и даже несколько ограничила ответные действия самой Черногории в отношении Дунайской монархии [Там же, док. 189]. По этой причине князь угрожал немедленно начать войну с Австро-Венгрией без оглядки на мнение России, которая «лишает его в такое тяжелое для всего сербства время средств обороны», и пригласил Потапова наблюдателем на показательные военные совещания по данному вопросу. Этими действиями, по мнению Потапова, князь лишь поднимал «воинственный шум», который сам военный агент объяснял «не столько серьезными намерениями воевать с Австриею, сколько желанием досадить России» [Потапов, док. 189, с. 347]. Тем не менее в ответах князю сам Потапов был вынужден прибегать к «братским» метафорам и уверять во взаимной искренней «привязанности» русского и черногорского народов [Там же, док. 189].

На помощь России в осуществлении политических проектов, основанных на идеях славянской взаимности, искренне рассчитывали не только в Черногории, но и в других южнославянских государствах. А. Л. Шемякин, к примеру, указывал, что среди первоочередных союзников для реализации своих «заговорщицких планов» по созданию сербо-болгарской федерации Никола Пашич рассматривал именно официальную Россию. И лишь отчаявшись найти союзника в ее лице, он обратился к помощи «революционных и патриотических организаций» [Шемякин, 2014, с. 137].

Продвигая и отстаивая в рамках своей политики панславистские формулы, Россия в отдельные моменты попадала в состояние зависимости от этого дискурса, когда «малые» государства в отношениях с ней стремились применять его на пользу себе. Подобный «братский фильтр» в сознании русских функционеров, преломлявший восприятие всего славянского (и особенно южнославянского) в панславистском ключе, воспринимался офицерами Генерального штаба как должное. Даже предполагая за ними определенное критическое отношение к подобной риторике, факт «просачивания» ее в официальные документы директивного характера говорит о значительном доминировании русской версии панславизма в русском общественном сознании начала XX века. Если с ним и не соглашались, то в любом случае вынужденно считались.

Тем не менее на фоне Боснийского кризиса 1908-1909 годов и падения репутации АвстроВенгрии среди населения независимых южнославянских государств [Потапов, док. 248, 262] воплощение подобной идеи в жизнь означало лидирующие позиции в реализации проекта балканского союза С. Д. Сазонова и подобных ему [РГАЛИ. Ф. 1696. Оп. 1. Ед. хр. 56. Л. 1-2]. Однако Балканские войны 1912-1913 годов внесли серьезные изменения в систему балканской политики, породив противоречия, препятствовавшие объединению балканских государств. В этой связи, достигнув пика, политическое влияние панславизма стало спадать, а после распада империи и большевизации России отошло на второй план.

В контексте событий на Балканах, вызванных появлением новых независимых государств в результате Великого восточного кризиса 1875-1878 годов, обострился спрос на новую внутриимперскую и внешнеполитическую идентичность. Частично он мог быть удовлетворен с 
помощью концепций славянофилов [Рокина, 2005]. Формирование идентичностей в имперском контексте происходило в условиях противостояния геополитических пространств [Евгеньева, 2012, с. 27-30] и при «использовании других» или в поиске «своих» в «чужом» (периферийном) этноконгломерате [Нойман, 2004].

В этом случае вполне закономерно также и то, что в сфере влияния близ границ одной крупной социокультурной общности с другой, однозначно воспринимаемой как «враг», «конкурент», может находиться специфическая зона. Народонаселение этой зоны, а точнее его образ, совмещает в себе черты, присущие одновременно обоим соседствующим и конкурирующим полюсам, при этом не важно, образует ли народонаселение такой зоны третью малую социокультурную общность или нет, ибо в отношении этого народонаселения, как правило, не происходит однозначной реакции по формуле «свой - чужой», а в отношении всей зоны соответственно не происходит четкого понимания, является ли она враждебной или дружественной. Получается, что людей, населяющих данную территорию, в представлении жителей одного из полюсов силы, невозможно в полной мере назвать «своими», как и невозможно называть их «другими». Через познание же другого и чужого нация логически идентифицирует в сравнении с ним и себя [Миллер, 2010].

В такой, «не до конца чужой» «буферной зоне» формировались русские представления о «малых» южнославянских народах на контрасте противостояния с «другой» Европой, в частности Австро-Венгрией, которая в сознании дипломатов все более замещала в качестве балканского противника - Османскую империю [Копылов, 2017]. Как итог, в русском общественном сознании возникла связь панславистской идеологии с представлениями о «малых» балканских народах.

Исследователи отмечают перспективность изучения образов Балкан [Шемякин, 2004], которые отражены в записях путешественников, в частности подданных Российской империи [Гусев, 2019]. Рост воинственных настроений в России в последние предвоенные годы, помимо прочего, возник под влиянием широко растиражированных образов угнетаемых «братских» народов [Там же]. Конкретизированные в словесных описаниях, рисунках и фотографиях, эти образы были меньшей абстракцией, чем идеологически сконструированная панславистская риторика, поэтому трансляция образов в публичное пространство способствовала подкреплению подобной риторики.

Благодаря широкому введению в научный оборот большого корпуса архивных источников, синхронных записей, воспоминаний и иных славяно-балканских травелогов [Открытие «братьевславян», 2018], стало возможным проведение комплексного анализа указанного материала. Как отмечает исследователь той его части, что относится к первой половине XIX века, уже этот период увенчался законченной версией «братских» представлений, закрепившейся в сознании славянофильской молодежи [Белов, 2017]. В конечном итоге именно эта гипотеза «братства» была адаптирована русскими панславистами, благодаря прекрасному сочетанию еe c основными дискурсивными константами панславизма.

Оформляя образы южных славян в массовом сознании, литература путешествий и подобные ей популярные издания оказывали влияние и на генезис панславистской идеи, опиравшейся на эти образы. В свою очередь панславистская концепция, в определенные периоды становясь идеологическим сопровождением российской внутренней и внешней политики [Григорьева, 2013], определяла жизнь, быт и сознание жителей страны, в том числе и отправлявшихся по различным причинам на Балканы. Здесь новый путешественник усваивал образ новых для себя этнореалий с учетом уже имевшихся у него представлений и идеологических координат, что создавало накопительный эффект и закрепляло панславистские идеи.

\section{Заключение}

Описанный в статье комплекс представлений о панславизме даже после формального краха имперской панслависткой доктрины в результате событий 1917 года и поражения белых в Гражданской войне, сохранял значение как политическая память и механизм психологической адаптации беженцев, вытесненных победителями-большевиками из страны. Многие из них осели в славянских странах - Болгарии, Королевстве сербов, хорватов и словенцев (Югославии) и Чехословакии. Примером одного из таких беженцев может служить судьба белогвардейца, донского казака, поэта и режиссера Сергея Федоровича Сулина. Как и многие участники Донского корпуса генерала Врангеля после поражения южных сил в Крыму, С. Ф. Сулин бежал на корабле в Турцию, где вместе с частью сослуживцев попал в лагеря Галлиполи и Лемноса, а позднее эмигрировал в Болгарию. В его эпигонских стихах бесконечно воспроизводятся штампы панславистского нарратива: 
«Приплыть на братский зов», «Великие Балканы», «...здесь рвали рабства цепь солдаты-исполины», «Белый Царь и Белый генерал», «...герои Шишкинских и всех орлиных гнезд», «...костьми на поле чести слечь», «...бились дружно вы, добыв свободу, деды», «И не воскреснет вновь российский наш солдат?!» [РГАЛИ. Ф. 2273. Оп. 1. Ед. хр. 1. Л. 3-25]. Кроме того, прослеживается и горечь переживаний автора за поражение в Гражданской войне, когда не удалось отстоять истинную «старую» Россию. Образ новой Родины, еще ранее бывшей для русского сознания, пронизанного панславистским мироощущением, «не до конца чужой», помог Сулину справиться с потерей прежней России, а сама панславистская идея имперского образца продолжала жить в сознании русских эмигрантов. Не удивительно и то, что ряд черт, характерных для панславистской идеологии, воспроизводился и в новой, Советской России, хотя уже в ином идеологическом контексте [Гришина, 2014].

Таким образом, русская панславистская концепция на протяжении XIX столетия и позднее находилась не только в перманентном взаимодействии с образом «малых» южнославянских народов в русском общественно-политическом сознании, но и зависела от актуального геополитического «веса» России, во многом опираясь на него, и от восприятия российской мощи в Европе. Панславизм русского образца развивался параллельно с мифом о «братьях-славянах». Он опирался на данный миф, реагировал на текущую политическую обстановку, учитывал иные проекты переустройства Балкан, например, австро-венгерский «триализм». В конечном итоге это привело к постепенному, но масштабному проникновению панславистского дискурса в общественное сознание и политическую повестку дня поздней Российской империи.

\section{ИСТОЧНИКИ И ПРИНЯТЫЕ СОКРАЩЕНИЯ}

1. Ламанский В. И. Об историческом изучении греко-славянского мира в Европе // Геополитика панславизма / сост., предисл., коммент. Ю. В. Климаков, отв. ред. О. А. Платонов. - М. : Ин-т русской цивилизации, 2010. - С. 42-183.

2. Ламанский В. И. Три мира Азийско-Европейского материка // Геополитика панславизма / сост., предисл., коммент. Ю. В. Климаков, отв. ред. О. А. Платонов. — М. : Ин-т русской цивилизации, 2010. — С. $183-323$.

3. Ламанский В. И. Россия уже тем полезна славянам, что она существует (посвящается И. С. Аксакову) // Геополитика панславизма / сост., предисл., коммент. Ю. В. Климаков, отв. ред. О. А. Платонов. - М. : Ин-т русской цивилизации, 2010. - С. 432-462.

4. Ламанский В. И. Речь в Славянском обществе // Геополитика панславизма / сост., предисл., коммент. Ю. В. Климаков, отв. ред. О. А. Платонов. - М. : Ин-т русской цивилизации, 2010. - С. 480-490.

5. Вступительное чтение доцента Петербургского университета В. И. Ламанского // Геополитика панславизма / сост., предисл., коммент. Ю. В. Климаков, отв. ред. О. А. Платонов. - М. : Ин-т русской цивилизации, 2010. - С. 491-515.

6. Ламанский В. И. Западнославянские вопросы занимательны для нас и в мирное время // Геополитика панславизма / сост., предисл., коммент. Ю. В. Климаков, отв. ред. О. А. Платонов. — М. : Ин-т русской цивилизации, 2010. - С. 539-560.

7. Ламанский В. И. Национальная бестактность // Геополитика панславизма / сост., предисл., коммент. Ю. В. Климаков, отв. ред. О. А. Платонов. - М. : Ин-т русской цивилизации, 2010. - С. 615-634.

8. Ламанский В. И. Чтения о славянской истории в Императорском С.-Петербургском университете // Геополитика панславизма / сост., предисл., коммент. Ю. В. Климаков, отв. ред. О. А. Платонов. - М. : Инт русской цивилизации, 2010. - С. 699-741.

9. Открытие «братьев-славян»: русские путешественники на Балканах в первой половине XIX века / сост., предисл., биогр. справ., коммент. и закл. ст. М. В. Белова. — СПб. : Нестор-История, 2018. — 672 с.

10. Потапов Н. М. Русский военный агент в Черногории. - Т. 1 : Донесения, рапорты, телеграммы, письма 1902-1915 гг. - М. : Подгорица, 2003. — 791 с.

11. РГАЛИ - Российский государственный архив литературы и искусства. — Ф. 191. — Оп. 1. — Ед. хр. 1824. — 90 л. ; Ф. 1696. - Оп. 1. - Ед. хр. 56. - 11 л. ; Ф. 2273. — Оп. 1. - Ед. хр. 1. — 79 л.

12. Рокина Г. В. Теория славянской взаимности в истории словацко-русских научных и культурных связей XIX века : автореф. дис. ... канд. ист. наук. - Казань, 2005. - 45 с.

13. Саприкина О. В. Академик В. И. Ламанский (1833-1914): научное наследие и общественная деятельность : дис. ... канд. ист. наук : 07.00.09. — М., 2004. — 294 с. 
1. Аксенова Е. П. А. Н. Пыпин о славянстве. - М. : Индрик, 2006. - 504 с.

2. Белов М. В. «Молодые славянофилы» на пути к «славянскому братству»: балканские путешествия 1840-х гг. // Славяноведение. - 2017. — № 2. - С. 96-112.

3. Болдин В. А., Прокудин Б. А. Эволюция панславистских взглядов В. И. Ламанского в начале XX в. // Каспийский регион: политика, экономика, культура. - 2019. - № 3 (60). - С. 158-167.

4. Волков В. К. К вопросу о происхождении терминов «пангерманизм» и «панславизм» // Славяногерманские культурные связи и отношения : сб. ст. / отв. ред. В. Д. Королюк. - М. : Наука, 1969. - С. 25-69.

5. Григорьева А. А. Балканская политика России и панславизм в 80-е годы XIX - начала XX века // Исторические, философские, политические и юридические науки, культурология и искусствоведение. Вопросы теории и практики. — Тамбов : Грамота, 2012. — № 6-1 (20). — С. 78-82.

6. Григорьева А. А. Панславизм: идеология и политика (40-е годы XIX — начало XX века). Иркутск : Аспринт, 2013. - 200 с.

7. Гришина Р. П. Большевистские планы строительства Балканской коммунистической федерации. 1920-е гг. // Балканы в европейских политических проектах XIX-XXI вв. : сб. ст. / отв. ред. Р. П. Гришина. М. : Ин-т славяноведения РАН, 2014. - С. 241-266.

8. Гусев Н. С. Южные славяне в начале XX века: перспективы и сложности научного подхода // Славяноведение. - 2019. - № 1. - С. 3-14.

9. Евгеньева Т. В. Историческая память и национально-государственная идентичность в современной России // Ценности и смыслы. — 2012. — № 5. — С. 27-36.

10. Кудряшев В. Н. Трансформация славянофильства в панславизм как смена концепции русского национализма // Вестник Томского государственного университета. — 2012. — № 364. - С. 65-71.

11. Ковтуненко М. К. Концепция политического панславизма И. И. Дусинского // Социальногуманитарные знания. - 2015. - № 3. - С. 222-227.

12. Копылов Н. А. Австро-Венгрия и Россия на полях Первой мировой войны. История одного мифа // Славяне и Россия: проблемы войны и мира на Балканах. XVIII-XXI вв. : сб. ст. / отв. ред. С. И. Данченко. - М. : Ин-т славяноведения РАН, 2017. - С. 371-388.

13. Лаптева Л. П. В.И. Ламанский и славянская тема в русских журналах рубежа XIX-XX веков // Славянский вопрос. Вехи истории. - М. : Ин-т славяноведения РАН, 1997. - С. 118-129.

14. Ливен Д. Российская империя и ее враги с XVI века до наших дней. — М. : Европа, 2007. — 688 c.

15. Миллер А. И. Империя Романовых и национализм : эссе по методологии исторического исследования. - 2-е изд., испр. и доп. - М. : Новое литературное обозрение, 2010. — 316 с.

16. Никифоров К. В. Россия и славянская идея в XX веке // Балканы в европейских политических проектах XIX-XXI вв. : сб. ст. / отв. ред. Р. П. Гришина. - М. : Ин-т славяноведения РАН, 2014. - С. 9-18.

17. Нойманн И. Б. Использование «Другого» : образы Востока в формировании европейских идентичностей : пер. с англ. - М. : Новое изд-во, 2004. - 335 с.

18. Одесский М. П. Автобиографическая публицистика М. А. Бакунина и идеология «славянской взаимности» // Вестник Российского государственного гуманитарного университета. Серия: История. Философия. Культурология. Востоковедение. Раздел: История. Исторические науки. — 2012. — № 13 (93). — C. $153-170$.

19. Павленко О. В. Панславизм // Славяноведение. - 1998. - № 6. - С. 43-60.

20. Писарев Ю. А. Великие державы и Балканы накануне Первой мировой войны. — М. : Наука, 1985. $-285 \mathrm{c}$.

21. [Рецензия] / М. В. Белов // Славяноведение. 2009. - № 1. - С. 107-111. — Рец. на кн.: Русские о Сербии и сербах. - Т. 1 : Письма, статьи, мемуары / сост., вступ. ст., заключ. А. Л. Шемякина; коммент. А. А. Силкина, А. Л. Шемякина. - СПб. : Алетейя, 2006. - 685 с.

22. Фатеев В. А. В спорах о самобытном пути России // Славянофильство: PRO ET CONTRA : творчество и деятельность славянофилов в оценке русских мыслителей и исследователей : антология. - СПб. : Рус. христианская гуманитарная академия, 2006. - С. 7-54.

23. Фролова М. М. Болгары в восприятии гвардейских офицеров, участников Русско-турецкой войны 1877-1878 гг. // Славяне и Россия: проблемы войны и мира на Балканах. XVIII-XXI вв. : сб. ст. / отв. ред. С. И. Данченко. - М. : Институт славяноведения РАН, 2017. - С. 87-113.

24. Шемякин А. Л. «Мир детства» сербов в путевых записках П. А. Ровинского // Славянский альманах. - М., 2004. - С. 72-93.

25. Шемякин А. Л. Никола Пашич и проект сербско-болгарского союза (1870-1880-е гг.) // Балканы в европейских политических проектах XIX-XXI вв. : сб. ст. / отв. ред. Р. П. Гришина. - М. : Ин-т славяноведения РАН, 2014. - С. 135-150.

26. Engelstein L. Slavophile Empire: Imperial Russia’s Illiberal Path. Ithaca: Cornell University Press, 2009. $-239 \mathrm{p}$. 


\section{Сведения об авторе}

Рыхтик Павел Павлович - аспирант кафедры новой и новейшей истории Института международных отношений и мировой истории Нижегородского государственного университета имени Н. И. Лобачевского.

Сфера научных интересов: проекты политического переустройства балканского региона в общественно-политическом дискурсе начала XX века.

Контактная информация: электронный адрес: rykhtikpavel@yandex.ru

\section{P. P. Rykhtik}

\section{Tracing Pan-Slavism \\ in Official Documents of the Military Department of the Russian Empire in the Early 20th Century *}

The article traces the influence of the ideology of Pan-Slavism on the interaction of major and minor countries in the Balkans in the early $20^{\text {th }}$ century. Pan-Slavism is treated as a social and political philosophy which originated in the $19^{\text {th }}$ century to become a versatile and heterogeneous concept, which is differently interpreted by different theoreticians. The article focuses on Russian Pan-Slavism as a variety of this philosophy typical of social and political discourse of the late Russian Empire. The article highlights the great influence exerted upon Russian Pan-Slavism by the following factors: Russian objectives in the Balkans, the idea of Slavic fraternity, the popularity of Slavophilism in Russia at the turn of the $19^{\text {th }}-20^{\text {th }}$ centuries. The article analyzes the process of gradual penetration of Pan-Slavic ideas shared by late Slavophiles, V. I. Lamansky in particular, into official texts (plans, reports, analytical notes) issued by the General Headquarters of the Russian Empire in the early $20^{\text {th }}$ century and devoted to the discussion of Russian military and political influence on the system of international relations in the Balkans in the early $20^{\text {th }}$ century. The author focuses on the peculiarities of the Pan-Slavic penetration and the image of Southern Slavs in the Russian Empire. The author also focuses on the idea of Slavic fraternity and the political situation in Russia.

the Balkans; Lamansky V. I.; Slavic fraternity; Russian Pan-Slavism; international relations

\section{SOURCES AND ABBREVIATIONS}

1. Lamanskij V. I. Historical Research of the Greek and Slavic World in Europe. Geopolitika panslavizma [Geopolitics of Pan-Slavism]. (Comp.) Klimakov Ju. V., (Ed.) Platonov O. A. Moscow, Institute for Russian Civilization Publ., 2010, pp. 42-183. (In Russian).

2. Lamanskij V. I. The Three Worlds of Eurasia. Geopolitika panslavizma [Geopolitics of Pan-Slavism]. (Comp.) Klimakov Ju. V., (Ed.) Platonov O. A. Moscow, Institute for Russian Civilization Publ., 2010, pp. $183-323$. (In Russian).

3. Lamanskij V. I. The Mere Fact the Russia Exists is Good for Slavs (dedicated to I. S. Aksakov). Geopolitika panslavizma [Geopolitics of Pan-Slavism]. (Comp.) Klimakov Ju. V., (Ed.) Platonov O. A.. Moscow, Institute for Russian Civilization Publ., 2010, pp. 432-462. (In Russian).

4. Lamanskij V. I. Speech in Slavic Community. Geopolitika panslavizma [Geopolitics of Pan-Slavism]. (Comp.) Klimakov Ju. V., (Ed.) Platonov O. A. Moscow, Institute for Russian Civilization Publ., 2010, pp. $480-490$. (In Russian).

5. Introductory Readings of V. I. Lamansky, an Associate Professor at St. Petersburg University. Geopolitika panslavizma [Geopolitics of Pan-Slavism]. (Comp.) Klimakov Ju. V., (Ed.) Platonov O. A. Moscow, Institute for Russian Civilization Publ., 2010, pp. 491-515. (In Russian).

6. Lamanskij V. I. The West Slavs Issues which are Relevant in Peaceful Times. Geopolitika panslavizma [Geopolitics of Pan-Slavism]. (Comp.) Klimakov Ju. V., (Ed.) Platonov O. A. Moscow, Institute for Russian Civilization Publ., 2010, pp. 539-560. (In Russian).

7. Lamanskij V. I. National Indiscretion. Geopolitika panslavizma [Geopolitics of Pan-Slavism]. (Comp.) Klimakov Ju. V., (Ed.) Platonov O. A. Moscow, Institute for Russian Civilization Publ., 2010, pp. 615-634. (In Russian).

8. Lamanskij V. I. Readings in Slavic History at St. Petersburg Imperial University. Geopolitika panslavizma [Geopolitics of Pan-Slavism]. (Comp.) Klimakov Ju. V., (Ed.) Platonov O. A. Moscow, Institute for Russian Civilization Publ., 2010, pp. 699-741. (In Russian).

\footnotetext{
* Rykhtik P. P. Tracing Pan-Slavism in Official Documents of the Military Department of the Russian Empire in the Early 20th Century. Vestnik Rjazanskogo gosudarstvennogo universiteta imeni S. A. Esenina [The Bulletin of Ryazan State University named for S. A. Yesenin]. 2020, no. 2 (67), pp. 25-36. (In Russian). https://doi.org/ 10.37724/RSU.2020.67.2.003
} 
9. Otkrytie “brat'ev-slavjan”: russkie puteshestvenniki na Balkanah v pervoj polovine XIX veka [Discovering Slavic Brethren: Russian Explorers in the Balkans in the First Half of the 19th Century]. (Comp.) Belov M. V. St. Petersburg, Nestor-History Publ., 2018, 672 p. (In Russian).

10. Potapov N. M. Russkij voennyj agent v Chernogorii. Tom 1: Donesenija, raporty, telegrammy, pis'ma 1902-1915 godov [Russian Military Agents in Montenegro. Vol. 1: Reports, Telegrams, and Letters in 1902-1915]. Moscow, Podgoritsa Publ., 2003, 791 p. (In Russian).

11. РГАЛИ (Russian State Archive of Literature and Arts) - Rossijskij gosudarstvennyj arhiv literatury $i$ iskusstva [Russian State Archive of Literature and Arts]. F. 191, Op. 1, Ed. hr. 1824, 90 1.; F. 1696, Op. 1, Ed. hr. 56, 11 1.; F. 2273, Op. 1, Ed. hr. 1, 79 1. (In Russian).

12. Rokina G. V. Teorija slavjanskoj vzaimnosti v istorii slovacko-russkih nauchnyh i kul'turnyh svjazej XIX veka [The Theory of Slavic Fraternity in the History of Slovak-Russian Research and Cultural Connections of the 19th Century]. Kazan, 2005. 45 p. (In Russian).

13. Saprikina O. V. Akademik V. I. Lamanskij (1833-1914): nauchnoe nasledie $i$ obshhestvennaja dejatel'nost' [Academician V. I. Lamansky (1833-1914): Scholarly Research and Social Activity]. Moscow, 2004. 294 p. (In Russian).

\section{REFERENCES} (In Russian).

1. Aksenova E. P. A. N. Pypin o slavjanstve [A. N. Pypin about Slavs]. Moscow, Indrik Publ., 2006, 504 p.

2. Belov M. V. Young Slavophiles on their Way to Slavic Fraternity: Traveling in the Balkans in the 1840s. Slavjanovedenie [Slavic Studies]. 2017, no. 2, pp. 96-112. (In Russian).

3. Boldin V. A., Prokudin B. A. The Evolution of V. I. Lamansky's Pan-Slavism in the Early 20th Century. Kaspijskij region: politika, jekonomika, kul'tura [Caspian Region: Politics, Economics, Culture]. 2019, no. 3 (60), pp. 158-167. (In Russian).

4. Volkov V. K. To the Issue of the Origin of the Terms Pan-Germanism and Pan-Slavism. Slavjanogermanskie kul'turnye svjazi i otnoshenija [German- Slavic Cultural Relations]. (Ed.) Koroljuk V. D. Moscow, Science Publ., 1969, pp. 25-69. (In Russian).

5. Grigor'eva A. A. Russian Policy in the Balkans and Pan-Slavism in the 1980s - Early 20th Century. Istoricheskie, filosofskie, politicheskie i juridicheskie nauki, kul'turologija i iskusstvovedenie. Voprosy teorii i praktiki [Historical, Philosophical, Political, and Legal Sciences, Culturology and Art History. Theoretical and Applied Issues]. Tambov, Literacy Publ., 2012, no. 6-1 (20), pp. 78-82. (In Russian).

6. Grigor'eva A. A. Panslavizm: ideologija i politika (40-e gody XIX-nachalo XX veka) [Pan-Slavism: Ideology and Politics (1840s — early 20th Century]. Irkutsk, Asprint Publ., 2013, 200 p. (In Russian).

7. Grishina R. P. Bolshevists' Plans Related to the Establishment of the Balkan Communist Federation. The 1920s. Balkany v evropejskih politicheskih proektah XIX-XXI vekov [The Balkans in European Political Projects of the 19th - 21st Centuries]. (Ed.) Grishina R. P. Moscow, Institute of Slavic Studies of the Russian Academy of Sciences, 2014, pp. 241-266. (In Russian).

8. Gusev N. Southern Slavs in the Early 20th Century: Perspectives and Challenges of Scientific Research. Slavjanovedenie [Slavic Studies]. 2019, no. 1, pp. 3-14. (In Russian).

9. Evgen'eva T. V. Historical Memory and National Identity in Modern Russia. Cennosti i smysly [Values and Meanings]. 2012, no. 5, pp. 27-36. (In Russian).

10. Kudrjashev V. N. The Transformation of Slavophilism into Pan-Slavism as a Transformation of the Concept of Russian Nationalism. Vestnik Tomskogo gosudarstvennogo universiteta [Bulletin of Tomsk State University]. 2012, no. 364, pp. 65-71. (In Russian).

11. Kovtunenko M. K. I. I. Dusinsky's Concept of Political Pan-Slavism. Social'no-gumanitarnye znanija [Social and Humanitarian Knowledge]. 2015, no. 3, pp. 222-227. (In Russian).

12. Kopylov N. A. Austria-Hungary and Russia in the Battlefields of World War I. The History of a Myth. Slavjane i Rossija: problemy vojny i mira na Balkanah. XVIII-XXI veka [Slavs and Russia: War and Peace in the Balkans. The 18th - 19th Centuries]. (Ed.) Danchenko S. I. Moscow, Institute for Slavic Studies of the Russian Academy of Sciences Publ., 2017, pp. 371-388. (In Russian).

13. Lapteva L. P. V. I. Lamansky and Slavic Issues in Russian Journals at the Turn of the $19^{\text {th }}-20$ th Centuries. Slavjanskij vopros. Vehi istorii [Slavic Issues. Landmarks of History]. Moscow, Moscow, Institute for Slavic Studies of the Russian Academy of Sciences Publ., 1997, pp. 118-129. (In Russian).

14. Liven D. Rossijskaja imperija $i$ ee vragi s XVI veka do nashih dnej [The Russian Empire and its Adversaries from the 16th Century till Our Time]. Moscow, Europe Publ., 2007, 688 p. (In Russian).

15. Miller A. I. Imperija Romanovyh i nacionalizm: jesse po metodologii istoricheskogo issledovanija [The Romanov and Nationalism: an Essay on the Methodology of Historical Research]. Moscow, New Literary Observer Publ., 2010, 316 p. (In Russian).

16. Nikiforov K. V. Russia and Pan-Slavism in the 20th Century. Balkany v evropejskih politicheskih proektah XIX-XXI vekov [The Balkans of European Political Projects of the 19th-20th Centuries]. (Ed.) Grishina R. P. Moscow, Institute for Slavic Studies of the Russian Academy of Sciences Publ., 2014, pp. 9-18. (In Russian). 
17. Neumann I. B. Ispol'zovanie «Drugogo» : obrazy Vostoka v formirovanii evropejskih identichnostej [Uses of the Other: the "East" in European Identity Formation]. Moscow, New Publishers Publ., 2004, 335 p. (Transl. from English).

18. Odesskij M. P. M. A. Bakunin's Autobiographical Journalism and the Ideology of Pan-Slavism. Vestnik Rossijskogo gosudarstvennogo gumanitarnogo universiteta. Serija: Istorija. Filosofija. Kul'turologija. Vostokovedenie. Razdel: Istorija. Istoricheskie nauki [Bulletin of Russian State Humanitarian University. Series: History, Philosophy. Culturology. Oriental Studies. Section: History. Historical Sciences]. 2012, no. 13 (93), pp. 153170. (In Russian).

19. Pavlenko O. V. Pan-Slavism. Slavjanovedenie [Slavic Studies]. 1998, no. 6, pp. 43-60. (In Russian).

20. Pisarev Ju. A. Velikie derzhavy i Balkany nakanune Pervoj mirovoj vojny [Great Powers in the Balkans before World War I]. Moscow, Science Publ., 1985, 285 p. (In Russian).

21. Shemjakin A. L. (comp.). [Review]. M. V. Belov. Slavjanovedenie [Slavic Studies]. 2009, no. 1, pp. 107111. Book Review: Russkie o Serbii i serbah. Tom 1: Pis'ma, stat'i, memuary [Russians about Serbia and Serbs. Volume 1: Letters, Articles, Memoires]. St. Petersburg, Aleteya Publ., 2006, 685 p. (In Russian).

22. Fateev V. A. Disputing about Russian National Identity. Slavjanofil'stvo: PRO ET CONTRA: tvorchestvo i dejatel 'nost' slavjanofilov v ocenke russkih myslitelej i issledovatelej: antologija [Slavophilism. PRO ET CONTRA: Slavophiles' Creativity and Activity as Assessed by Russian Thinkers and Researchers: an Anthology]. St. Petersburg, Russian Christian Humanitarian Academy Publ., 2006, pp. 7-54. (In Russian).

23. Frolova M. M. Bulgarians as Viewed by Guard Officers, Participants of the Russo-Turkish War in the Balkans. The 18th-19th Centuries. (Ed.) Danchenko S. I. Moscow, Institute for Slavic Studies of the Russian Academy of Sciences Publ., 2017, pp. 87-113. (In Russian).

24. Shemjakin A. L. Serbian Children's World in P.A. Rovinsky's Travelling Notes. Slavjanskij al'manah [Slavic Almanac]. Moscow, 2004, pp. 72-93. (In Russian).

25. Shemjakin A. L. Nikola Pašić and the Project of Serbian-Bulgarian Union (1870s-1880s). Balkany v evropejskih politicheskih proektah XIX-XXI vekov [The Balkans in European Political Projects of the 19th-21st Centuries]. (Ed.) Grishina R. P. Moscow, Institute for Slavic Studies of the Russian Academy of Sciences Publ., 2014, pp. 135-150. (In Russian). 239 p.

26. Engelstein L. Slavophile Empire: Imperial Russia’s Illiberal Path. Ithaca: Cornell University Press, 2009,

\section{Information about the author}

Rykhtik Pavel Pavlovich - Postgraduate Student of the Department of New and Modern History at the Institute of International Relations and World History of Nizhny Novgorod State University named for N. I. Lobachevsky.

Research interests: projects of political restructuring of the Balkan Region in social and political discourse of the early 20th century.

Contact information: e-mail: rykhtikpavel@yandex.ru

Поступила в редакичюю 13.01.2020

Received 13.01.2020 